\title{
D-Gluconate Dehydrogenase, 2-Keto-D-gluconate Yielding, from Gluconobacter dioxyacetonicus: Purification and Characterization
}

\author{
Emiko Shinagawa, Kazunobu Matsushita, Osao Adachi \\ and Minoru AmEYama
}

Department of Agricultural Chemistry, Faculty of Agriculture, Yamaguchi University, Yamaguchi 753, Japan

Received November 30, 1983

\begin{abstract}
D-Gluconate dehydrogenase catalyzing the oxidation of D-gluconate to 2-keto-D-gluconate was solubilized with Triton X-100 from the membrane of Gluconobacter dioxyacetonicus IFO 3271 and purified to an almost homogeneous state by chromatographies on DEAE-cellulose and CMToyopearl in the presence of $0.1 \%$ Triton X-100. The enzyme had three subunits with molecular weights of 64,000, 45,000 and 21,000, and contained approximately $2 \mathrm{~mol}$ of heme per mol of the enzyme. The prosthetic group of the dehydrogenase was found to be a flavin covalently bound to the enzyme protein. The substrate specificity of the purified enzyme was very strict for D-gluconate and the apparent Michaelis constant for D-gluconate was $2.2 \mathrm{mM}$. The optimum $\mathrm{pH}$ and temperature of the purified enzyme were 6.0 and $40^{\circ} \mathrm{C}$, respectively.
\end{abstract}

The biochemical activity of acetic acid bacteria is characterized by the high oxidative activity for many organic compounds. Of the acetic acid bacteria, particularly strains in the genus Gluconobacter can oxidize D-glucose and D-gluconate to ketogluconates. Such oxidative activity can be taken as one of the important characteristics of Gluconobacter strains. The oxidative reaction is carried out in the cytoplasmic membrane and linked with the electron transport system of the organism. To investigate the localization of the primary dehydrogenase in such an oxidative system, we prepared spheroplasts of acetic acid bacteria ${ }^{1)}$ and determined the dehydrogenase activity using ferricyanide as an electron acceptor. ${ }^{2)}$ From the results, it was demonstrated that the primary dehydrogenases in such an oxidative system were localized on the outer surface of the cytoplasmic membrane unlike NADH, succinate or lactate dehydrogenases. This reasonably accounts for the rapid accumulation of such oxidation products. In Pseudomonas strains, membrane-bound D-glucose and D-gluconate dehydrogenases were also thought to be localized on the outer surface of the cytoplasmic membrane. ${ }^{3,4)}$ Gluconobacter strains produce 2-keto-Dgluconate (2KGA) and 5-keto-D-gluconate (5KGA) at the same time but other oxidative bacteria produce only 2KGA from D-gluconate. In the previous papers, we reported the purification and characterization of $\mathrm{D}^{-}$ gluconate dehydrogenase (GADH) catalyzing the oxidation of D-gluconate to $2 \mathrm{KGA}$ from Pseudomonas aeruginosa, ${ }^{5,6)}$ Klebsiella pneumoniae $^{7)}$ and Serratia marcescens. ${ }^{8)}$ These three GADHs were very similar to each other in subunit structure and catalytic properties.

Gluconobacter strains accumulate 2KGA and 5KGA in the culture medium at the same time, and the ratio of the two ketogluconate productions varies among strains and with culture conditions as reported previously. ${ }^{9}$ However, up to the present, it has been unclear how Gluconobacter strains regulate the production of $2 \mathrm{KGA}$ and $5 \mathrm{KGA}$. It was reported that $2 \mathrm{KGA}$ or $5 \mathrm{KGA}$ was formed without NAD or NADP by the particulate fraction of Gluconobacter strains, ${ }^{10,11)}$ however, a further study on GADH catalyzing the 
oxidation of D-gluconate has not been reported. Thus, it has remained unknown as to whether Gluconobacter strains possess two respective enzymes yielding $2 \mathrm{KGA}$ and $5 \mathrm{KGA}$ or one enzyme yielding both $2 \mathrm{KGA}$ and 5KGA. To resolve this question, we attempted to purify GADH catalyzing the oxidation of $\mathrm{D}$ gluconate from the membrane of Gluconobacter strains. In this work, we selected a strain which produced mainly 2KGA, and tried to purify GADH catalyzing the oxidation of D-gluconate to $2 \mathrm{KGA}$.

\section{MATERIALS AND METHODS}

Bacterial strain and cultivation. G. dioxyacetonicus IFO 3271 was supplied by the Institute for Fermentation, Osaka (IFO), and used throughout this work. The medium consisted of $10 \mathrm{~g}$ of sodium D-gluconate, $3 \mathrm{~g}$ of D-glucose, $2 \mathrm{~g}$ of D-sorbitol, $2 \mathrm{~g}$ of yeast extract and $2 \mathrm{~g}$ of polypepton in 1 liter of tap water. Cultivation was carried out aerobically in a shake flask or 50-liter jar fermentor at $30^{\circ} \mathrm{C}$.

Enzyme assay. D-Gluconate dehydrogenase was measured spectrophotometrically at $25^{\circ} \mathrm{C}$ by determining the initial reduction rate of 2,6-dichlorophenolindophenol (DCIP) at $600 \mathrm{~nm}$ as described in the previous paper. ${ }^{7)}$ One unit was defined as the amount of enzyme that catalyzed the oxidation of $1 \mu \mathrm{mol}$ of D-gluconate, or the reduction of $1 \mu \mathrm{mol}$ of DCIP, per minute under the standard assay conditions.

Protein determination. The protein content was determined according to the method by Lowry et al. ${ }^{12)}$ Crystalline bovine albumin was used as the standard. A modified method described by Dulley and Grieve ${ }^{13)}$ was also employed instead for samples which contained detergents.

Polyacrylamide gel electrophoresis. Polyacrylamide gel electrophoresis was carried out in $7.5 \%$ gel using Trisglycine buffer (pH 8.3) as described by Davis. ${ }^{14)}$ Sodium dodecyl sulfate (SDS)-polyacrylamide gel electrophoresis was carried out according to the method of Laemmli ${ }^{15}$ ) using $10 \%$ separating gel. The standard proteins used for the molecular weight determination were bovine serum albumin, $\mathrm{Mr}$ 68,000: ovalbumin, $\mathrm{Mr}$ 43,000: carbonic anhydrase, $\mathrm{Mr} 30,000$ and $\beta$-lactoglobulin, $\operatorname{Mr} 18,300$. Protein bands were stained with Coomassie brilliant blue.

Detection of the reaction product. The reaction mixture contained $100 \mu \mathrm{mol}$ of sodium D-gluconate, $0.3 \mu \mathrm{mol}$ of phenazine methosulfate, $100 \mu \mathrm{mol}$ of potassium phosphate buffer, $\mathrm{pH}$ 6.0, and the purified enzyme, and was incubated overnight at $30^{\circ} \mathrm{C}$. The reaction product was detected by paper chromatography as described previously. ${ }^{16)}$ Ketoacids were identified by coloration with 2,3,5-triphenyltetrazolium chloride or $o$-phenylenediamine $\cdot \mathrm{HCl}$ as described by Gossele et al. ${ }^{17)}$

Chemicals. Sodium D-gluconate was from Fujisawa Pharmaceutical Co. and yeast extract was from Oriental Yeast Co. CM-Toyopearl was a kind gift from Toyo Soda Manufacturing Co., Ltd. All other chemicals used in this work were commercial products.

\section{RESULTS}

Solubilization and purification of D-gluconate dehydrogenase

All steps were carried out at 0 to $5^{\circ} \mathrm{C}$ and $0.01 \mathrm{M}$ potassium phosphate buffer, $\mathrm{pH}$ 5.7, was used unless otherwise stated.

Step 1. Preparation of the membrane fraction. Cells were harvested at the late exponential phase and washed twice with water. The cell paste was suspended in the buffer and disrupted by passage through a French press at 20,000 psi. After centrifugation to remove intact cells, the supernatant was further centrifuged at $80,000 \times g$ for $1 \mathrm{hr}$. The resultant precipitate was collected as the membrane fraction.

Step 2. Solubilization. About $8 \mathrm{~g}$ of membrane was suspended in $80 \mathrm{ml}$ of a buffer containing $2 \%$ Triton X-100 and $0.1 \mathrm{~m}$ sodium D-gluconate. The suspension was stirred for $3 \mathrm{hr}$ in an ice bath and then centrifuged at $80,000 \times g$ for $1 \mathrm{hr}$. The precipitate was discarded and the supernatant was dialyzed overnight against two changes of 1 liter of the buffer containing $0.5 \%$ Triton X-100.

Step 3. DEAE-cellulose column chromatography. The dialysate was applied to a DEAE-cellulose column $(2.5 \times 10 \mathrm{~cm})$ equilibrated with the buffer containing $0.1 \%$ Triton X-100 and the column was washed with the same buffer. The enzyme activity was eluted during the washing of the column.

Step 4. CM-Toyopearl column chromatography (I). The resultant enzyme solution from the preceding step was applied on a CM-Toyopearl column $(1.5 \times 20 \mathrm{~cm})$ equili- 


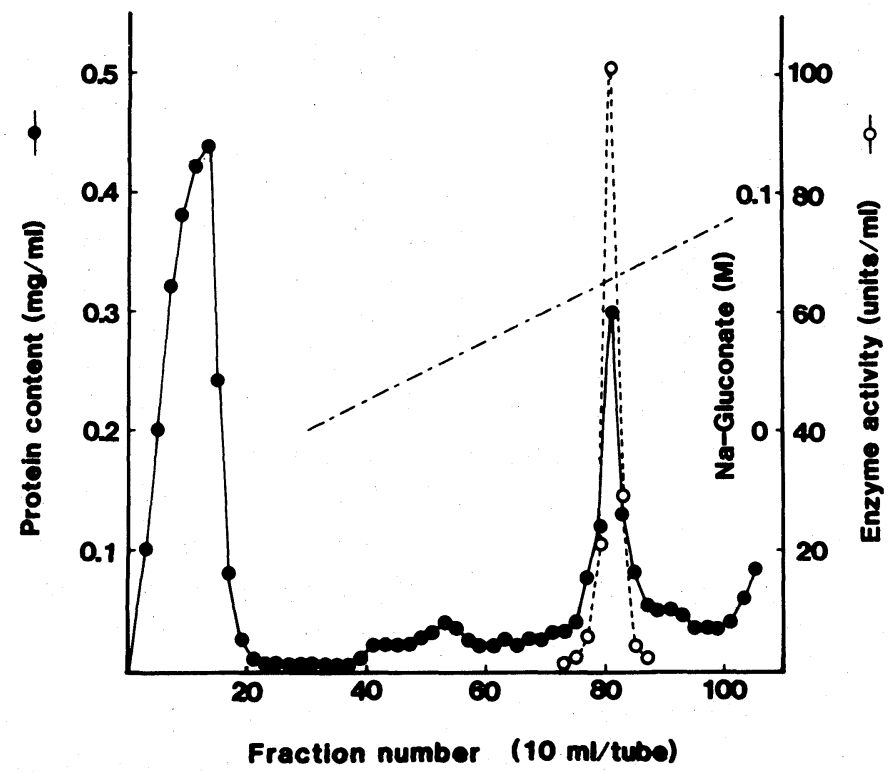

FIG. 1. Chromatography of D-Gluconate Dehydrogenase on CM-Toyopearl (I).

The column was equilibrated with $0.01 \mathrm{M}$ potassium phosphate buffer, pH 5.7, containing $0.1 \%$ Triton X-100. After removal of nonadsorbable proteins by washing with the same buffer, elution of the enzyme was achieved with a linear gradient of sodium D-gluconate to $0.1 \mathrm{M}(----)$.

Table I. Purification of D-Gluconate Dehydrogenase from Gluconobacter dioxyacetonicus IFO 3271

\begin{tabular}{lcccc}
\hline & $\begin{array}{c}\text { Total } \\
\text { protein } \\
(\mathrm{mg})\end{array}$ & $\begin{array}{c}\text { Total } \\
\text { activity } \\
\text { (units) }\end{array}$ & $\begin{array}{c}\text { Specific } \\
\text { activity } \\
\text { (units/mg) }\end{array}$ & $\begin{array}{c}\text { Yield } \\
(\%)\end{array}$ \\
\hline Membrane fraction & 1344 & 3612 & 2.7 & 100 \\
Solubilized fraction & 327 & 3698 & 11 & 102 \\
Dialysate & 233 & 3298 & 36 & 91 \\
DEAE-cellulose & 90 & 3248 & 193 & 90 \\
CM-Toyopearl (I) & 13 & 2511 & 237 & 70 \\
CM-Toyopearl (II) & 8.4 & 1980 & & 55 \\
\hline
\end{tabular}

brated with the buffer containing $0.1 \%$ Triton X-100. After the column was washed with the same buffer, GADH activity was eluted as a single peak with a linear gradient of sodium D-gluconate to $0.1 \mathrm{M}$ as shown in Fig. 1. The fractions containing enzyme activity were pooled and concentrated with polyethylene glycol 6000 . To the enzyme solution, polyethylene glycol 6000 was added to $25 \mathrm{~g} \mathrm{(w/v)}$ and the mixture stirred for $1 \mathrm{hr}$. The mixture was then centrifuged at $12,000 \times g$ for $10 \mathrm{~min}$ and the supernatant was discarded. The precipitate was dissolved in the buffer contain- ing $1 \%$ Triton $\mathrm{X}-100$ and insoluble material was removed by centrifugation.

Step 5. CM-Toyopearl column chromatography (II). The resultant supernatant from the preceding step was applied to a CM-Toyopearl column $(1.5 \times 5 \mathrm{~cm})$ equilibrated with the buffer containing $0.1 \%$ Triton X-100. After washing the column with the same buffer, the column was treated first with the same buffer containing $0.05 \mathrm{M} \mathrm{NaCl}$ and then with $0.2 \mathrm{M} \mathrm{NaCl}$. The enzyme activity was eluted from the column with the buffer containing $0.1 \%$ Triton X-100 and $0.2 \mathrm{M}$ 
$\mathrm{NaCl}$.

A summary of the enzyme purification is presented in Table I.

\section{Properties of the purified $G A D H$}

Absorption spectrum. The purified enzyme showed a typical spectrum of a cytochrome having maxima at 418,523 and $553 \mathrm{~nm}$ in the reduced form prepared by the addition of $D$ gluconate or dithionite (Fig. 2). The cytochrome was determined to be a $c$-type cytochrome from the pyridine hemochromogen and the content of cytochrome was calculated to be $15.2 \mathrm{nmol}$ per $\mathrm{mg}$ of enzyme protein. This value corresponded to $1.98 \mathrm{~mol}$ heme per mol of the enzyme.

Electrophoretic analyses. The purity of the enzyme was examined by conventional polyacrylamide gel electrophoresis. As shown in Fig. 3, the purified enzyme migrated as a single band, indicating that the purified enzyme preparation was homogeneous. The subunit structure was analyzed by SDS-gel electrophoresis and the purified enzyme was

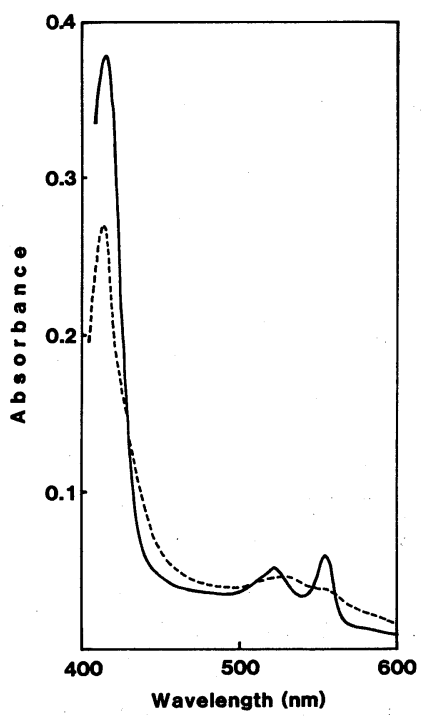

FIG. 2. Absorption Spectra of D-Gluconate Dehydrogenase.

The purified enzyme with a specific activity of 237 was used at a protein concentration of $0.13 \mathrm{mg} / \mathrm{ml}$ in $0.01 \mathrm{M}$ potassium phosphate buffer, $\mathrm{pH}$ 5.7. Dotted line, oxidized form; solid line, reduced form obtained by adding sodium dithionite. dissociated into three bands with molecular weights of $64,000,45,000$ and 21,000 (Fig. 3). The slowest moving band showed fluorescence under UV light and the second band was detected as a cytochrome by a staining method. ${ }^{18)}$ The sum of the molecular weights of the subunits was 130,000 .

Prosthetic group. The prosthetic group of GADH was thought to be a flavin covalently bound to the enzyme protein judging from the fluorescence on SDS-polyacrylamide gel on UV irradiation. The flavin moiety could not be extracted by cold trichloroacetic acid treatment but could be released when the enzyme was digested with pronase and trypsin. The content of the covalently bound flavin thus obtained was estimated to be about 1.26 nmol per $\mathrm{mg}$ protein and this value corresponded to about $0.16 \mathrm{~mol}$ flavin per mol of the enzyme. Due to difficulties in obtaining

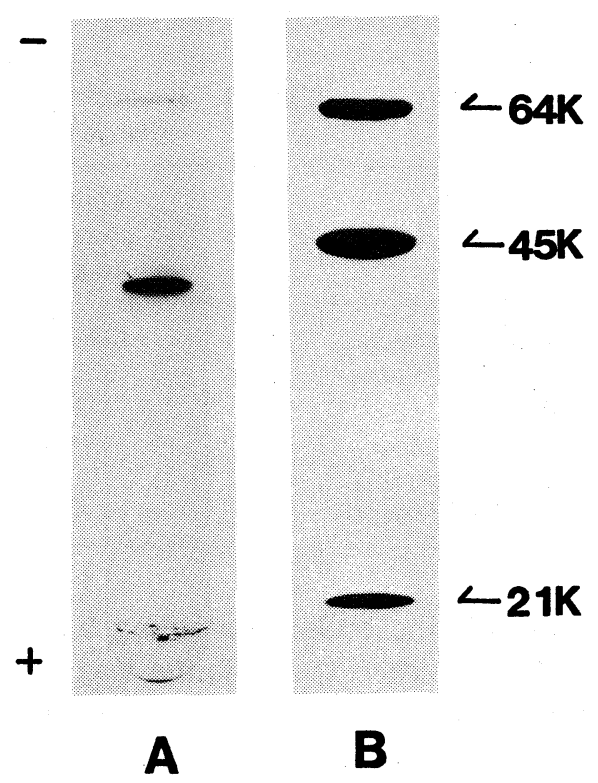

FIG. 3. Polyacrylamide Gel Electrophoresis of DGluconate Dehydrogenase.

The protein bands of both gels were stained with Coomassie brilliant blue and the direction of electrophoresis was from top to bottom. A, disc gel electrophoresis in the absence of SDS. B, slab gel electrophoresis in the presence of SDS. Bovine serum albumin (Mr 68,000), ovalbumin (Mr 43,000), carbonic anhydrase (Mr 30,000) and $\beta$-lactoglobulin (Mr 18,300) were used as markers for preparation of a calibration curve. 
complete proteolysis, the apparent flavin content was found to be somewhat lower than expected. As already reported, such underestimation of bound flavin was also observed at about $3 \mathrm{nmol}$ per $\mathrm{mg}$ protein with other enzyme such as other GADH ${ }^{5)}$ sorbitol dehydrogenase $^{19)}$ and 2KGA dehydrogenase. ${ }^{20)}$

Catalytic properties. Phenazine methosulfate, ferricyanide and DCIP were available as electron acceptors once the enzyme activity was solubilized from the membrane.

The substrate specificity of the enzyme was examined with various substrates including sugars, sugar alcohols and organic acids. Among these compounds, only D-gluconate was oxidized by the purified enzyme and the apparent Michaelis constant was estimated to be $2.2 \mathrm{~mm}$ at $\mathrm{pH} 6.0$. Thus, the substrate specificity of the enzyme was found to be very strict for D-gluconate.

The optimum $\mathrm{pH}$ and temperature of this enzyme in $\mathrm{D}$-gluconate oxidation were found to be 6.0 and $40^{\circ} \mathrm{C}$, respectively.

Reaction product. After the reaction mixture containing the purified enzyme, D-gluconate and phenazine methosulfate was incubated overnight at $30^{\circ} \mathrm{C}$, the reaction product was detected by paper chromatography. As a reaction product, only $2 \mathrm{KGA}$ was detected, 5KGA was not detected. So, the enzyme purified from $G$. dioxyacetonicus was characterized as a $2 \mathrm{KGA}$ yielding $\mathrm{GADH}$.

\section{DISCUSSION}

In the previous papers, we reported membrane-bound GADHs from $P$. aeruginosa, ${ }^{5,6)}$ $K$. pneumoniae $^{7)}$ and $S$. marcescens ${ }^{8)}$ which produced only 2KGA from D-gluconate during cultivation. The GADHs from these bacteria were very similar to each other in physico-chemical and catalytic properties.

This study concerned the purification and characterization of GADH from $G$. dioxyacetonicus IFO 3271. Unlike other oxidative bacteria such as $P$. aeruginosa, $K$. pneumoniae and $S$. marcescens, Gluconobacter strains oxidize Dgluconate and produce $2 \mathrm{KGA}$ and $5 \mathrm{KGA}$ at the same time during cultivation. The ratio of $2 \mathrm{KGA}$ formation to 5KGA formation varied among the strains and also with culture conditions, ${ }^{9)}$ however, the regulatory methanism for both ketogluconate productions has so far remained unclear. Although the existence of GADH in a Gluconobacter strain had been reported, ${ }^{10,11)}$ it was not clarified whether both ketogluconate formations were catalyzed by a single enzyme or a dual enzyme stystem. The GADH(s) catalyzing 2KGA and 5KGA formation was thought to be membrane-bound, since both ketogluconates accumulated so rapidly in the culture medium in large amounts. To clarify the regulatory mechanism in the two ketogluconate productions in Gluconobacter, we attempted to purify GADH catalyzing the oxidation of D-gluconate from a Gluconobacter strain. We selected $G$. dioxyacetonicus IFO 3271 which produced mainly $2 \mathrm{KGA}$. GADH was solubilized from the membrane with Triton X-100 and purified to an almost homogeneous state. The enzyme never produced 5KGA under various conditions. The purified enzyme was a flavoprotein-cytochrome $c$ complex and the cytochrome $c$ of the purified enzyme preparation was a partially reduced form. There was a great similarity between the properties of the purified GADHs from $P$. aeruginosa, K. pneumoniae and $S$. marcescens, and those of that of $G$. dioxyacetonicus.

The prosthetic group of GADH was found to be a covalently bound flavin the same as in cases of other GADHs, however, the content of flavin was lower than that of other GADHs. The apparent content of flavin might be small due to incomplete digestion of the enzyme or/and the reduced form of the flavin in the purified preparation similar to the case of the cytochrome $c$ component.

The apparent Michaelis constant for Dgluconate was somewhat greater than that of other GADHs. For this reason, it was thought that Gluconobacter strains grew generally on media containing higher concentrations of carbon source than other oxidative bacteria did. The optimum $\mathrm{pH}$ and temperature of the enzyme were 6.0 and $40^{\circ} \mathrm{C}$, respectively, and 
these optimum conditions were coincident with those for $2 \mathrm{KGA}$ production by resting cells as described previously. ${ }^{9}$ )

It was found that GADH purified from $G$. dioxyacetonicus oxidized D-gluconate to 2KGA but not to 5KGA, and was similar to other GADHs from $P$. aeruginosa, ${ }^{5,6)} \mathrm{K}$. pneumoniae $^{7)}$ and $S$. marcescens ${ }^{8)}$ in physicochemical and catalytic properties. Thus, Gluconobacter strains possess two GADHs: i.e. one is a 2KGA yielding GADH and the other is a 5KGA yielding GADH. At present, a study on the alternative GADH yielding 5KGA from other Gluconobacter strains is in progress.

Acknowledgments. The present work was supported in part by a grant from the Foundation for the Promotion of Research on Agricultural Chemistry. The authors wish to thank Mr. K. Yano and Miss A. Kusunoki for their skillful technical assistance.

\section{REFERENCES}

1) K. Matsushita, E. Shinagawa, O. Adachi and M. Ameyama, Agric. Biol. Chem., 45, 1515 (1981).

2) K. Matsushita, Y. Hiramoto, E. Shinagawa, O. Adachi and M. Ameyama, Proc. Ann. Meeting Agric. Chem. Soc., Japan, 1980, p. 392.
3) M. Midgley and E. W. Dawes, Biochem. J., 132, 141 (1973).

4) B. K. Roberts, M. Midgley and E. A. Dawes, J. Gen. Microbiol., 78, 319 (1973).

5) K. Matsushita, E. Shinagawa, O. Adachi and M. Ameyama, J. Biochem., 85, 1173 (1979).

6) K. Matsushita, E. Shinagawa, O. Adachi and M. Ameyama, J. Biochem., 86, 249 (1979).

7) K. Matsushita, E. Shinagawa and M. Ameyama, "Methods in Enzymology," Vol. 89, ed. by W. A. Wood, Academic Press Inc., New York, N. Y., 1982, p. 187.

8) E. Shinagawa, K. Matsushità, O. Adachi and M. Ameyama, Agric. Biol. Chem., 42, 2355 (1978).

9) E. Shinagawa, K. Matsushita, O. Adachi and M. Ameyama, J. Ferment. Technol., 61, 359 (1983).

10) J. De Ley and A. H. Stouthamer, Biochim. Biophys. Acta, 34, 171 (1959).

11) E. Galante, P. Scalaffa and G. A. Lanzani, Enzymologia, 27, 176 (1964).

12) O. H. Lowry, N. J. Rosebrough, A. L. Farr and R. J. Randall, J. Biol. Chem., 193, 265 (1951).

13) J. R. Dulley and P. A. Grieve, Anal. Biochem., 64, 136 (1975).

14) B. J. Davis, Ann. N. Y. Acad. Sci., 121, 404 (1964).

15) U. K. Laemmli, Nature, 227, 680 (1970).

16) E. Shinagawa, T. Chiyonobu, O. Adachi and $\mathbf{M}$. Ameyama, Agric. Biol. Chem., 40, 475 (1976).

17) F. Gossele, J. Swings and J. De Ley, Zbl. Bakt. Hyg., I. Abt. Orig. C1, 178 (1980).

18) P. E. Thomas, D. Ryan and W. Levin, Anal. Biochem., 75, 168 (1976). 